\title{
BISKUIT SUBSTITUSI TEPUNG LABU KUNING (Cucubita Moschata Duch) DAN TEPUNG KECAMBAH KEDELAI (Glycine max L. Merr) SEBAGAI KONTRIBUSI UNTUK PEMENUHAN ANGKA KECUKUPAN GIZI (AKG)
}

\author{
[Biscuit Production from Yellow Pumpkin (Cucubita moschata Duch) Flour and Soybean (Glycine max L. \\ Merr) Sprouts Flour Substitution to Fulfill Nutrition Adequacy Score (NAS)] \\ Wa Ode Nurul Maulidya Koila ${ }^{{ }^{*}, \text { La Karimuna² }}{ }^{2}$ Hermanto $^{1}$ \\ 1Jurusan Ilmu dan Teknologi Pangan, Fakultas Pertanian, Universitas Halu Oleo, Kendari \\ 2Jurusan Agroteknologi, Fakultas Pertanian, Universitas Halu Oleo, Kendari \\ *Email: dwisucizaitun01@gmail.comTelp:+6282188405741
}

Diterima tanggal 10 April 2019

Disetujui tanggal 20 Juni 2019

\begin{abstract}
The purpose of this research was to study the effect of pumpkin flour (Cucurbita Moschata Duch) and soybean sprout flour (Glycine max L. Merr) substitution on organoleptic assessment, nutritional content and nutritional contribution of biscuit products. This study used a completely randomized design (CRD) with various percentages of pumpkin flour and soybean sprouts flour substitution treatment, namely T0 (100\%: 0\% : 0\%), T1 (50\% : 45\%: 5\%), T2 (50\%: 40\%: 10\%), T3 (50\%: 35\%: 15\%), T4 (50\%: 30\% : 20\%), and T5 (50\%: 25\%:25\%). The results show the substitution of pumpkin flour and soybean sprouts flour had a very significant effect on the characteristics of color, aroma, taste, and texture. T1 treatment was the most preferred by the panelists with preference scores of color, aroma, taste, and texture reached 3.56 (like), 3.40 (slightly like), 3.52 (like), and 3.64 (like), respectively. Meanwhile, the descriptive scale rating shows the panelists' preference scores of color, aroma, and texture reached 3.62 (brown-yellow), 3.42 (slight aroma of pumpkin and soybeans sprouts), and 3.02 (slightly hard), respectively. The selected product contained $11.91 \%$ protein, $3.62 \%$ ash, $17.98 \%$ fat, $57.46 \%$ carbohydrate, and $9.00 \%$ water. Based on the RDA for the interlude meal, the energy contribution of the T1 treatment was $122.90 \mathrm{kcal}$. The $T 1$ treatment biscuit product was preferred by panelists. The protein and fat contents of the product met the national standard for biscuits.
\end{abstract}

Keywords: substitution, pumpkin flour, soybean sprout flour, biscuits

\section{ABSTRAK}

Tujuan dari penelitian ini untuk mempelajari pengaruh substitusi tepung labu kuning (Cucurbita Moschata Duch) dan tepung kecambah kedelai (Glycine max L. Merr) terhadap penilaian organoleptik, kandungan gizi dan kontibusi zat gizi produk biskuit. Penelitian ini menggunakan Rancangan Acak Lengkap (RAL) dengan berbagai presentase perlakuan substitusi tepung labu kuning dan tepung kecambah kedelai yaitu T0 (100\%: $0 \%: 0 \%)$, T1 (50\%: 45\%: 5\%, T2 (50\% : 40\%: 10\%), T3 (50\%: 35\%: 15\%), T4 (50\%:30\%:20\%) dan T5 (50\%: 25\%: 25\%). Hasil penelitian menunjukan substitusi tepung labu kuning dan tepung kecambah kedelai berpengaruh sangat nyata terhadap karakteristik warna, aroma, rasa, dan tekstur. Perlakuan T1 merupakan perlakuan yang paling disukai panelis dengan skor penilain kesukaan terhadap warna sebesar 3,56 (suka), aroma sebesar 3,40 (agak suka), rasa sebesar 3,52 (suka) dan tekstur sebesar 3,64 (suka), sedangkan penilaian skala deskriptif yang disukai panelis terhadap parameter warna sebesar 3,62 (Kuning kecoklatan), 
aroma sebesar 3,42 (agak berbau khas labu kuning dan kecambah kedelai) dan untuk tekstur sebesar 3,02 (agak keras). Kadar protein sebesar 11,91\%, kadar abu 3,62\%, kadar lemak 17,98\%, kadar karbohidrat $57,46 \%$ dan kadar air sebesar 9,00\%. Berdasarkan AKG makanan selingan kontribusi energi perlakuan T1 yaitu 122,90 kkal. Produk biskuit perlakuan T1 dapat diterima dan lebih disukai panelis. Kadar air, abu dan karbohidrat tidak memenuhi standar SNI biskuit, sedangkan kadar protein dan lemak telah memenuhi standar SNI biskuit.

Kata kunci: substitusi, tepung labu kuning, tepung kecambah kedelai, biskuit

\section{PENDAHULUAN}

Pangan dan gizi sangat erat kaitannya dengan upaya peningkatan sumber daya manusia. Ketersediaan pangan yang cukup untuk seluruh penduduk disuatu wilayah belum dapat digunakan sebagai jaminan akan terhindarnya dari masalah pangan dan gizi. Karena selain ketersediaan perlu diperhatikan pola konsumsi atau keseimbangan kontribusi diantara jenis pangan, sehingga memenuhi standar gizi tertentu (Laura dan Jenifer, 2006), dan untuk menentukan pemenuhan gizi yang diperlukan sangat tergantung pada Angka Kecukupan Gizi (AKG). Tingkat kecukupan zat gizi adalah rata-rata asupan gizi harian yang cukup untuk memenuhi kebutuhan gizi dalam kelompok umur, jenis kelamin dan fisiologis tertentu. Ketidak seimbangan tingkat kecukupan zat gizi dapat menimbulkan masalah gizi, baik masalah gizi kurang maupun gizi lebih (Kurniasih et al., 2010).

Makanan selingan atau cemilan merupakan faktor yang penting bagi pertumbuhan, karena jajanan menyumbangkan energi dan zat gizi yang diperlukan sehingga jajanan yang berkualitas baik akan mempengaruhi kualitas makanan (Murphy et al., 2007). Seseorang rata-rata memilih makanan selingan atau cemilan dengan kandungan energi dan protein yang rendah sehingga sumbangan energi dan protein dari makanan jajanan terhadap total konsumsi sehari - hari masih rendah. Oleh karena itu diperlukan makanan yang sehat untuk meningkatkan nilai gizi.

Labu kuning sebagai bahan makanan memiliki keunggulan yaitu kandungan gizinya cukup lengkap, seperti betakaroten, kalsium, fosfor, besi, kalium dan natrium, vitamin B1, tinggi akan vitamin C. Sekitar $100 \mathrm{~g}$ labu kuning mengandung kalori 29,00 kal, protein $1,10 \mathrm{~g}$, lemak $0,30 \mathrm{~g}$, hidrat arang $6,60 \mathrm{~g}$, kalsium 45,00 mg, fosfor $64,00 \mathrm{mg}$, zat besi 1,40mg, vitamin A 180,00 Sl, vitamin B1 0,08 mg, vitamin C 52,00 g dan air 91,20g. Nutrisi yang dikandungnya menjadikan labu kuning berkasiat meningkatkan kekebalan tubuh. Betakaroten yang terkandung didalam labu kuning berperan mencegah serangan jantung. Sementara kandungan vitamin B1, C dan 
seratnya berperan sebagai pencegah penyakit jantung dan stroke. Manfaat lain labu kuning adalah mengobati demam, migrain, diare, penyakit ginjal, gout, serta membantu menyembuhkan radang (Hendrasti, 2003).

Salah satu alternatif pengolahan labu kuning yang saat ini menjadi pilihan adalah dibuat menjadi tepung. Tepung labu kuning menjadi pilihan karena produk dapat disimpan untuk jangka waktu yang lama dan dengan mudah diolah menjadi bahan pangan formulasi (Que et al., 2008), terutama produk bakery, sup, mie instan, pasta dan tepung komposit sebagai pengayaan bahan fungsional dan bahan pewarna alami (Dhiman et al., 2009). Tepung labu kuning yang di hasilkan mengandung karbohidrat 78,77\%, protein 3,74\%, lemak 1,34\% serat kasar 2,90\%, betakaroten $7,29 \mathrm{mg} / 100 \mathrm{~g}$. Tepung labu kuning baik digunakan untuk bahan fortifikasi pangan terutama makanan anak - anak sehingga dapat meningkatkan nilai gizinya (Elmi, 2010).

Kecambah kedelai merupakan salah satu bahan makanan sumber protein nabati. Kadar protein pada kecambah kedelai sekitar $9 \mathrm{~g} / 100 \mathrm{~g}$ bahan, sedangkan saat ditepungkan, kadar proteinnya menjadi 37,5 g/100 g bahan. Kecambah kedelai memiliki protein yang lebih mudah dicerna dari pada kedelai karena ikatan protein kedelai diubah menjadi bentuk yang lebih aktif. Kedelai juga memiliki zat anti gizi yaitu asam fitat dan tripsin inhibitor, namun aktivitas zat anti gizi ini dapat dikurangi dengan adanya perkecambahan (Nwamaka, 2008). Tepung kecambah kedelai memberikan keuntungan yaitu dapat menghilangkan berbagai senyawa antigizi di dalamnya serta dapat meningkatkan mutu gizi pada kecambah kedelai. Kecambah dalam bentuk tepung mempunyai daya guna lebih luas (Aminah, 2012).

Biskuit merupakan salah satu jenis makanan kering yang digemari masyarakat (Nurdjanah et al., 2014). Produk ini merupakan produk kering yang memiliki kadar air rendah. Biskuit seringkali dikonsumsi sebagai makanan selingan disamping makanan pokok. Sebagai makanan selingan, diharapkan dapat menyumbangkan energi dan sebagai pengganti energi yang telah dikeluarkan. Pada umumnya biskuit kaya akan energi, terutama berasal dari sumber karbohidrat dan lemak, lemak yang ditambahkan pada biskuit yang berfungsi untuk melembutkan atau membuat renyah, sehingga menjadi lebih lezat (Astawan, 2009). Protein dapat juga digunakan sebagai bahan bakar apabila keperluan energi tubuh tidak terpenuhi oleh karbohidrat dan lemak (Winarno, 2004).

Berdasarkan pemaparan sebelumnya, maka dilaporkan hasil penelitian mengenai kandungan gizi dan organoleptik biskuit substitusi tepung labu kuning (Cucurbita moschata Duch) dan tepung kecambah kedelai (Glycine max L. Merr) sebagai kontribusi untuk pemenuhan angka kecukupan gizi (AKG). Di samping itu, tepung kecambah kedelai merupakan sumber protein yang cukup tinggi, sehingga menjadikan kecambah kedelai sebagai 
salah satu sumber makanan yang memiliki kandungan protein berkualitas baik dan dapat dikombinasikan dalam pembuatan biskuit.

\section{BAHAN DAN METODE}

\section{Bahan}

Bahan yang digunakan pada penelitian ini antara lain tepung labu kuning, tepung kecambah kedelai, telur, gula halus, margarine, tepung terigu, vanili, garam, tepung terigu, susu, baking powder. Bahan kimia yang digunakan dalam penelitian ini yaitu $\mathrm{HCl}$ (teknis), alkohol 95\% (teknis), $\mathrm{NaOH} \mathrm{50 \%} \mathrm{(teknis),} \mathrm{CuSO}_{4}$ (teknis), $\mathrm{NaKC}_{4} \mathrm{O}_{6}$ (teknis), $6 \mathrm{H}_{2} \mathrm{O}$ (teknis), etanol (teknis), BSA (Bovine Serum Albumin) (Sigma), reagen Biuret (teknis), heksan (teknis), TBA (Sigma), asam asetat (teknis), dan $\mathrm{HCl}$ (teknis).

\section{Tahapan Penelitian}

\section{Pembuatan Tepung Labu Kuning (Ahmad, 2012)}

Pembuatan tepung labu modifikasi Ahmad (2012), pertama-tama kulit buah labu kuning dikupas, kemudian buah labu dicuci, lalu dipotong kecil-kecil kemudian dilakukan pengeringan menggunakan alat oven pada suhu $60{ }^{\circ} \mathrm{C}$ selama 12 jam, selanjutnya digiling dan diayak menggunakan ayakan ukuran 80 mesh.

\section{Pembuatan Tepung Kecambah Kedelai (Khaidar, 2016)}

Pembuatan tepung kecambah kedelai modifikasi Khaidar (2016), kedelai hasil sortasi, Kemudian direndam selama 6 jam dengan air bersih, kemudian ditiriskan, selanjutnya kedelai dimasukan ke dalam ember yang bagian dalamnya dilubangi. Ember kemudian ditutup untuk mencegah masuknya cahaya matahari. Pengecambahan dilakukan pada suhu ruang slama 28 jam. Selama proses pengecambahan, kedelai disiram air setiap selang waktu 3 jam. Kecambah kedelai selanjutnya dikukus selama 5 menit, selanjutnya di keringkan menggunakan alat oven pada suhu $50^{\circ} \mathrm{C}$ selama 8 jam. setelah kering, kecambah kedelai ditepungkan dengan menggunakan alat blender dan diayak menggunakan ayakan 80 mesh.

\section{Pembuatan Biskuit (Kanaka et al., 2015)}

Pembuatan biskuit berbahan dasar tepung labu kuning dan tepung kecambah kedelai dalam penelitian ini yaitu kuning telur $15 \mathrm{~g}$ dikocok dengan gula halus $20 \mathrm{~g}$, mentega $30 \mathrm{~g}$, susu bubuk $10 \mathrm{~g}$, vanili $1 \mathrm{~g}$ dikocok selama 
10 menit menggunakan alat mixer. Setelah bahan tercampur rata dan mengembang, ditambahkan tepung labu kuning dan tepung kecambah kedelai sesuai perlakuan kemudian diaduk merata sampai kalis. Adonan yang sudah tercampur rata dibentuk pipih lalu dicetak. Selanjutnya dipanggang menggunakan alat oven $150^{\circ} \mathrm{C}$ selama 20 menit.

\section{Penilaian Organoleptik (Oktaviani, 2018)}

Uji organoleptik ini bermaksud untuk mengetahui tingkat penerimaan panelis terhadap kualitas produk biskuit. Penilaian organoleptik skala hedonik dan deskriptif meliputi penilaian kesukaan terhadap warna, aroma, rasa dan tekstur. Uji organoleptik dilakukan dengan mengisi lembar respon panelis oleh 30 panelis semi terlatih, panelis memberikan skor sesuai tanggapan panelis terhadap produk biskuit dengan skala yang digunakan untuk skala hedonik adalah $5=$ sangat suka, $4=$ suka, $3=$ agak suka, $2=$ tidak suka, dan $1=$ sangat tidak suka, sedangkan skala deskriptif untuk warna $5=$ sangat cokleat $4=$ coklat kekuningan, $3=$ kuning kecoklatan $2=$ kuning, dan $1=$ puth kecoklatan untuk aroma adalah $5=$ sangat berbau khas labu kuning dan tepung kecambah kedelai, 4 = berbau khas labu kuning dan kecambah kedelai $3=$ agak berbau khas labu kuning dan kecambah kedelai 2 = tidak berbau khas labu kuning dan kecambah kedelai 1 = sangat tidak berbau khas labu kuning dan kecambah kedelai. Sedangkan untuk tekstur adalah $5=$ sangat keras, $4=$ keras, $3=$ agak keras, $2=$ tidak keras, 1 = sangat tidak keras.

\section{Analisis Nilai Gizi}

Analisis nilai gizi meliputi analisis kadar air menggunakan metode thermogravimetri (AOAC, 2005), analisis kadar abu menggunakan metode pengabuan kering (AOAC, 2005), analisis kadar protein menggunakan metode Biuret (AOAC, 2005), analisis kadar lemak menggunakan metode ekstrasi soxhlet (AOAC, 2005) dan analisis kadar karbohidrat yang dihitung berdasarkan by difference (AOAC, 2005).

\section{Takaran Saji dan \%AKG}

Perhitungan takaran saji dalam penelitian ini dihitung berdasarkan jumlah Angka Kecukupan Gizi (AKG) Untuk makanan selingan atau makanan jajan (BPOM No 13, 2016).

\section{Rancangan Penelitian}

Penelitian ini menggunakan Rancangan Acak Lengkap (RAL) yaitu pembuatan biskuit substitusi tepung labu kuning dan tepung kecambah kedelai dengan menggunakan enam perlakuan. Perlakuan substitusi tepung labu kuning dan tepung kecambah kedelai berdasarkan tepung terigu adalah : $\mathrm{T}_{0}=0 \%$ Tepung labu kuning : $0 \%$ tepung kecambah kedelai : 100\% Tepung terigu, $\mathrm{T}_{1}=45 \%$ Tepung labu kuning : $5 \%$ Tepung kecambah kedelai : 
$50 \%$ Tepung terigu, $\mathrm{T}_{2}=40 \%$ Tepung labu kuning : 10\% Tepung kecambah kedelai : 50\% Tepung terigu, $\mathrm{T}_{3}=$ $35 \%$ Tepung labu kuning : 15\% Tepung kecambah kedelai : 50 : Tepung terigu, $\mathrm{T}_{4}=30 \%$ Tepung labu kuning : 20\% Tepung kecambah kedelai : 50\% Tepung terigu, $T_{5}=25 \%$ Tepung labu kuning : 25\% Tepung kecambah kedelai : 50\% Tepung terigu. Masing-masing perlakuan diulang sebanyak tiga kali sehingga menghasilkan 18 unit percobaan. Formulasi dalam rancangan ini berdasarkan hasil penelitian pendahuluan.

\section{Analisis Data}

Data dianalisa dengan menggunakan sidik ragam (Analysis of Variances), diperoleh perlakuan uji organoleptik yang berpengaruh nyata terhadap variabel pengamatan, dilanjutkan dengan uji Duncan' Multiple Range Test (DMRT) pada taraf kepercayaan $95 \%(\alpha=0,05)$.

\section{HASIL DAN PEMBAHASAN}

\section{Uji Organoleptik Skala hedonik}

Rekapitulasi hasil analisis ragam (ANOVA) produk biskuit substitusi tepung labu kuning dan tepung kecambah kedelai terhadap penilaian organoleptik yang meliputi penilaian warna, aroma, tekstur dan rasa disajikan pada Tabel 1.

Tabel 1. Rekapitulasi analisis ragam pengaruh substitusi tepung labu kuning terhadap uji organoleptik dan nilai gizi biskuit sebagai kontribusi untuk pemenuhan AKG yang meliputi penilaian warna, aroma, rasa dan tekstur.

\begin{tabular}{ccc}
\hline No & Variabel Pengamatan & Analisis Ragam \\
\hline 1 & Organoleptik warna & $* *$ \\
2 & Organoleptik aroma & $* *$ \\
3 & Organoleptik rasa & $* *$ \\
4 & Organoleptik tekstur & $* *$ \\
\hline
\end{tabular}

Keterangan: ${ }^{* *}=$ Berpengaruh sangat nyata

Berdasarkan hasil analisis ragam pada Tabel 1 menunjukkan bahwa penambahan tepung labu kuning dan tepung kecambah kedelai pada biskuit berpengaruh sangat nyata terhadap penilaian organoleptik warna, rasa, aroma dan tekstur. 
Warna

Berdasarkan hasil analisis ragam diketahui bahwa perlakuan penambahan tepung labu kuning dan tepung kecambah kedelai menunjukkan berpengaruh sangat nyata terhadap penilaian organoleptik warna. Hasil uji lanjut Duncan's Multipe Range Test (DMRT0,05) dapat dilihat pada Tabel 2.

Tabel 2. Rerata hasil penilaian organoleptik warna biskuit tepung labu kuning dan tepung kecambah kedelai

\begin{tabular}{ccc}
\hline Perlakuan $(\mathrm{TT}:$ TKK : TLK) & Rerata Organoleptik Warna & Kategori \\
\hline T0 $(100 \%: 0 \%: 0 \%)$ & $3,06^{\mathrm{bc}} \pm 1,03$ & Agak Suka \\
T1 $(50 \%: 45 \%: 5 \%)$ & $3,56^{\mathrm{a}} \pm 0,77$ & Suka \\
T2 $(50 \%: 40 \%: 10 \%)$ & $3,34^{\mathrm{ab}} \pm 3,04$ & Agak Suka \\
T3 $(50 \%: 35 \%: 15 \%)$ & $2,79^{\mathrm{c}} \pm 0,87$ & agak Suka \\
T4 $(50 \%: 30 \%: 20 \%)$ & $2,89^{\mathrm{bc}} \pm 0,77$ & Agak Suka \\
T5 $(50 \%: 25 \%: 25 \%)$ & $2,73^{\mathrm{c}} \pm 0,85$ & Tidak Suka \\
\hline
\end{tabular}

Keterangan: Angka-angka yang diikuti oleh huruf yang berbeda menunjukan beda nyata berdasarkan uji DMRT 0,05 taraf kepercayaan 95\%. TT (tepung terigu), TLK (tepung labu kuning), TKK (tepung kecambah kedelai)

Ber dasarkan Tabel 2 penilaian panelis tertinggi terhadap parameter warna diperoleh pada perlakuan T1 dengan nilai rata-rata 3.56. Hal ini sejalan dengan penelitian yang di laporkan Tresnani et al. (2015) pada penelitian snack bar tepung ubi jalar dan tepung kecambah kedelai yang menyatakan tingkat kesukaan panelis terhadap warna snack bar meningkat seiring dengan meningkatnya proporsi tepung komposit. Warna snack bar pada taraf perlakuan P3 cenderung lebih gelap dikarenakan adanya reaksi non enzimatis yaitu reaksi maillard. Reaksi maillard ini merupakan hasil browning non enzimatis antara asam amino lisin pada tepung kecambah kedelai dengan gugus gula pereduksi hasil hidrolisis yang terdapat pada tepung ubi jalar kuning dalam suasana panas sehingga menyebabkan warna bahan makanan menjadi kecoklatan (Zulfa, 2013).

\section{Aroma}

Berdasarkan hasil analisis ragam diketahui bahwa perlakuan penambahan tepung labu kuning dan tepung kecambah kedelai menunjukkan berpengaruh sangat nyata terhadap penilaian organoleptik aroma. Hasil uji lanjut Duncan's Multipe Range Test (DMRT0,05) dapat dilihat pada Tabel 3.

Tabel 3. Rerata hasil penilaian organoleptik aroma biskuit tepung labu kuning dan tepung kecambah kedelai

\begin{tabular}{ccc}
\hline Perlakuan $(\mathrm{TT}:$ TKK : TLK) & Rerata Organoleptik Aroma & Kategori \\
\hline T0 $(100 \%: 0 \%: 0 \%)$ & $3,03^{\mathrm{b}} \pm 0,98$ & Agak Suka \\
T1 $(50 \%: 45 \%: 5 \%)$ & $3.40^{\mathrm{a}} \pm 1,00$ & Agak Suka \\
T2 $(50 \%: 40 \%: 10 \%)$ & $2,88^{\mathrm{b}} \pm 0,92$ & Agak Suka \\
T3 $(50 \%: 35 \%: 15 \%)$ & $2,34^{\mathrm{c}} \pm 0,87$ & Agak Suka \\
T4 $(50 \%: 30 \%: 20 \%)$ & $2,42^{\mathrm{c}} \pm 0,82$ & Agak Suka \\
T5 $(50 \%: 25 \%: 25 \%)$ & $2,38^{\mathrm{c}} \pm 1,03$ & Agak Suka \\
\hline
\end{tabular}

Keterangan: Angka-angka yang diikuti oleh huruf yang berbeda menunjukan beda nyata berdasarkan uji DMRT 0,05 taraf kepercayaan 95\%. TT (tepung terigu), TLK (tepung labu kuning), TKK (tepung kecambah kedelai) 
Penilaian panelis tertinggi terhadap parameter aroma diperoleh pada nilai rerata tingkat kesukaan aroma tertinggi yaitu 3,40 pada perlakuan $\mathrm{T}_{1}$ (tepung terigu 50\%: 45\% Tepung labu kuning : 5\% tepung kecambah kedelai). Hal ini diduga karena adanya penambahan tepung labu kuning dan tepung kecambah kedelai sehingga meningkatkan aroma dari biskuit. Hal ini sejalan dengan penelitian yang di laporkan Tresnani et al. (2015) pada penelitian, substitusi tepung komposit ubi jalar kuning (Ipomea batatas L.) dan kecambah kedelai (glycine max L. Merr) pada pembuatan snack bar Tingkat kesukaan panelis terhadap aroma berkisar antara $35-60 \%$ untuk kategori suka dan $30-60 \%$ untuk kategori sangat suka. Tingkat kesukaan panelis terhadap aroma snack bar cenderung meningkat seiring dengan peningkatan proporsi tepung komposit ubi jalar kuning dan kecambah kedelai. Aroma yang timbul adalah aroma khas cake yang gurih, aroma kacang merah dan aroma langu pada snack bar yang berasal dari tepung kecambah kedelai.

Nilai rerata tingkat kesukaan panelis yang paling rendah yaitu 2,34 pada perlakuan $\mathrm{T}_{3}(50 \%$ tepung terigu : $35 \%$ tepung labu kuning : 15\% tepung kecambah kedelai). Hal ini diduga karena tingginya proposi tepung kecambah kedelai yang di tambahkan kedalam adonan. bau langu yang terdapat didalam tepung kecambah kedelai mengakibatkan menurunnya tingkat kesukaan panelis terhadap aroma biskuit tersebut. Sesuai dengan pernyataan Sari dan Adi (2017) pada penelitan cookies substitusi tepung daun kelor dan tepung kecambah kedelai. Semakin banyak substitusi tepung daun kelor dan tepung kecambah kedelai maka semakin rendah pula tingkat kesukaan panelis hal ini terjadi karena tepung daun kelor dan tepung kecambah kedelai memiliki aroma langu.

\section{Rasa}

Berdasarkan hasil analisis ragam diketahui bahwa perlakuan penambahan tepung labu kuning dan tepung kecambah kedelai menunjukkan berpengaruh nyata terhadap penilaian organoleptik rasa. Hasil uji lanjut Duncan's Multipe Range Test (DMRT0,05) dapat dilihat pada Tabel 4.

Tabel 4. Rerata hasil penilaian organoleptik rasa biskuit tepung labu kuning dan tepung kecambah kedelai

\begin{tabular}{ccc}
\hline Perlakuan (TT: TKK : TLK) & Rerata Organoleptik Rasa & Kategori \\
\hline T0 $(100 \%: 0 \%: 0 \%)$ & $2,49 \mathrm{bc} \pm 0,97$ & Tidak Suka \\
T1 $(50 \%: 45 \%: 5 \%)$ & $3,52^{\mathrm{a}} \pm 1,36$ & Suka \\
T2 $(50 \%: 40 \%: 10 \%)$ & $2,49 \mathrm{bc} \pm 1,02$ & Tidak Suka \\
T3 $(50 \%: 35 \%: 15 \%)$ & $2,37 \mathrm{c} \pm 0,95$ & Tidak Suka \\
T4 $(50 \%: 30 \%: 20 \%)$ & $2,64 \mathrm{~b} \pm 0,90$ & Agak Suka \\
T5 $(50 \%: 25 \%: 25 \%)$ & $2,47^{\mathrm{bc}} \pm 0,84$ & Tidak Suka \\
\hline
\end{tabular}

Keterangan: Angka-angka yang diikuti oleh huruf yang berbeda menunjukan beda nyata berdasarkan uji DMRT 0,05 taraf kepercayaan 95\%. TT (tepung terigu), TLK (tepung labu kuning), TKK (tepung kecambah kedelai) 
Nilai rerata tingkat kesukaan rasa tertinggi yaitu 3,52 pada perlakuan $\mathrm{T}_{1}$ (tepung terigu 50\% : 45\% Tepung labu kuning : $5 \%$ tepung kecambah kedelai). Hal ini diduga karena semakin tinggi proporsi tepung labu kuning dan semakin rendah proposi tepung kecambah kedalam yang ditambahkan maka rasa pada biskuit cenderung lebih manis dan gurih sehingga cenderung lebih disukai oleh panelis. Hal ini sejalan dengan penelitian yang di laporkan Tresnani et al. (2015), substitusi tepung komposit ubi jalar kuning (Ipomea batatas L.) dan kecambah kedelai (glycine max L. Merr) pada pembuatan snack bar. Tingkat kesukaan panelis terhadap rasa berkisar antara $35-70 \%$ untuk kategori suka dan $20-50 \%$ untuk kategori sangat suka.

Tingkat kesukaan panelis terhadap rasa cenderung meningkat seiring dengan peningkatan proporsi tepung komposit ubi jalar kuning dan kecambah kedelai. Hal ini dikarenakan semakin tinggi proporsi tepung komposit, rasa snack bar cenderung lebih manis dan gurih sehingga cenderung lebih disukai oleh panelis. Rasa manis snack bar timbul karena adanya tepung ubi jalar kuning yang juga menambah rasa manis selain dari gula pasir, sedangkan rasa gurih timbul oleh adanya tepung kecambah kedelai yang memiliki kadar lemak lebih tinggi dari tepung terigu yakni masing - masing $24,09 \mathrm{~g} / 100 \mathrm{~g}$ dan 1,3 g/100 g. Menurut Winarno (2004), penambahan lemak dimaksudkan untuk meningkatkan kalori serta memperbaiki tekstur, dan citarasa bahan pangan. Hal ini sesuai dengan pernyataan Muchtadi (2010) bahwa salah satu fungsi lemak dalam makanan adalah untuk meningkatkan palatabilitas (rasa enak, lezat) dimana sebagian besar senyawa atau zat yang bertanggung jawab terhadap flavor makanan bersifat larut dalam lemak.

\section{Tekstur}

Berdasarkan hasil analisis ragam diketahui bahwa perlakuan penambahan tepung labu kuning menunjukkan berpengaruh sangat nyata terhadap penilaian organoleptik tekstur dapat dilihat pada Tabel 5 .

Tabel 5. Analisis penerimaan organoleptik tekstur biskuit tepung labu kuning dan tepung kecambah kedelai

\begin{tabular}{ccc}
\hline Perlakuan (TT: TKK: TLK) & Rerata Organoleptik Tekstur & Kategori \\
\hline T0 $(100 \%: 0 \%: 0 \%)$ & $2,82^{\mathrm{b}} \pm 0,83$ & Agak Suka \\
T1 $(50 \%: 45 \%: 5 \%)$ & $3,64^{\mathrm{a}} \pm 0,83$ & Suka \\
T2 $(50 \%: 40 \%: 10 \%)$ & $2,84^{\mathrm{b}} \pm 0,90$ & Agak Suka \\
T3 $(50 \%: 35 \%: 15 \%)$ & $2,69^{\mathrm{b}} \pm 1,03$ & Agak Suka \\
T4 $(50 \%: 30 \%: 20 \%)$ & $2,81^{\mathrm{b}} \pm 0,87$ & Agak Suka \\
T5 $(50 \%: 25 \%: 25 \%)$ & $2,77^{\mathrm{b}} \pm 0,86$ & Agak Suka \\
\hline
\end{tabular}

Keterangan: Angka-angka yang diikuti oleh huruf yang berbeda menunjukan beda nyata berdasarkan uji DMRT 0,05 taraf kepercayaan 95\%. TT (tepung terigu), TLK (tepung labu kuning), TKK (tepung kecambah kedelai)

Nilai rerata tingkat kesukaan tekstur tertinggi yaitu 3,64 pada perlakuan $\mathrm{T}_{1}$ (tepung terigu $50 \%: 45 \%$ Tepung labu kuning : $5 \%$ tepung kecambah kedelai). Hal ini diduga tekstur pada biskuit lebih keras dikarenakan 
tingginya proposi penambahan tepung labu pada biskuit. Sesuai dengan pernyataan Permatasarii et al. (2018) pada penelitian chiffon cake berbahan dasar tepung labu kuning dan tepung mocaf. Semakin tinggi konsentrasi penambahan tepung labu kuning menyebabkan kekerasan meningkat sebagai akibat pengembangan yang kurang baik atau menurunkan volume chiffon cake sehingga menjadi lebih padat dan terasa lebih keras.

\section{Uji Organoleptik Skala Deskriptif}

Rekapitulasi hasil analisis ragam (ANOVA) produk biskuit penambahan tepung labu kuning dan tepung kecambah kedelai terhadap penilaian organoleptik yang meliputi penilaian warna, aroma, dan tekstur disajikan pada Tabel 6 .

Tabel 6. Rekapitulasi analisis ragam pengaruh substitusi tepung labu kuning terhadap uji organoleptik dan nilai gizi biskuit sebagai kontribusi untuk pemenuhan AKG yang meliputi penilaian warna, aroma, dan tekstur.

\begin{tabular}{ccc}
\hline No & Variabel Pengamatan & Analisis Ragam \\
\hline 1 & Organoleptik warna & ${ }^{* *}$ \\
2 & Organoleptik aroma & ${ }^{* *}$ \\
3 & Organoleptik tekstur & $* *$ \\
\hline
\end{tabular}

Keterangan : ** berpengaruh sangat nyata

Berdasarkan hasil analisis ragam pada Tabel 6 Berdasarkan hasil analisis ragam pada Tabel 6 menunjukkan bahwa penambahan tepung labu kuning dan tepung kecambah kedelai pada biskuit berpengaruh sangat nyata terhadap penilaian organoleptik warna, aroma dan tekstur.

\section{Warna}

Berdasarkan hasil analisis ragam diketahui bahwa perlakuan penambahan tepung labu kuning dan tepung kecambah kedelaimenunjukkan berpengaruh sangat nyata terhadap penilaian organoleptik warna. Hasil uji lanjut Duncan's Multipe Range Test (DMRTo,05) dapat dilihat pada Tabel 7.

Tabel 7. Analisis organoleptik deskriptif penilaian organoleptik warna biskuit tepung labu kuning dan tepung kecambah kedelai

\begin{tabular}{ccc}
\hline Perlakuan $(\mathrm{TT}:$ TKK $:$ TLK) & Rerata Organoleptik Warna & Kategori \\
\hline T0 $(100 \%: 0 \%: 0 \%)$ & $2,1^{\mathrm{c}} \pm 0.59$ & putih kecoklatan \\
T1 $(50 \%: 45 \%: 5 \%)$ & $2.94^{\mathrm{b}} \pm 0.84$ & Agak kuning kecoklatan \\
T2 $(50 \%: 40 \%: 10 \%)$ & $3.62^{\mathrm{a}} \pm 0.55$ & Kuning kecoklatan \\
T3 $(50 \%: 35 \%: 15 \%)$ & $2.83^{\mathrm{b}} \pm 0.89$ & Agak kuning kecoklatan \\
T4 $(50 \%: 30 \%: 20 \%)$ & $2.91^{\mathrm{b}} \pm 0.89$ & Agak kuning kecoklatan \\
T5 $(50 \%: 25 \%: 25 \%)$ & $2.71^{\mathrm{b}} \pm 0.88$ & Agak kuning kecoklatan \\
\hline
\end{tabular}

Keterangan: Angka-angka yang diikuti oleh huruf yang berbeda menunjukan beda nyata berdasarkan uji DMRT 0,05 taraf kepercayaan 95\%. TT (tepung terigu), TLK (tepung labu kuning), TKK (tepung kecambah kedelai) 
Penilaian panelis tertinggi terhadap parameter warna di peroleh pada T2 (50\% tepung terigu : $35 \%$ tepung labu kuning: 15\%) dengan warna kuning kecoklatan. Pengaruh terhadap indikator warna pada biskuit substitusi tepung labu kuning dan tepung kecambah kedelai disebabkan oleh faktor presentase penambahan tepung labu kuning dan tepung kecambah kedelai yang digunakan dan proses pengolahan bahan substitusi. Hal ini sejalan dengan pernyataan Utami (2012). Bahan pangan yang mengalami pengolahan atau pemanasan dapat diduga mengalami perubahan warna. Proses pemanasan atau pengeringan makanan mengubah kualitas fisik dan kimianya.

Menurut See et al. (2007). Menyatakan warna pada tepung labu kuning yang dominan berwarna kuningjingga sehingga mempengaruhi warna produk akhir makanan. Intensitas warna cake yang dihasilkan dipengaruhi oleh tingkat formulasi tepung labu kuning yang digunakan, sehingga semakin banyak penggunaan tepung labu kuning maka warna cake akan semakin coklat. Avianty dan Ayustaningwarno, (2013) menyatakan bahwa cookies dengan penambahan tepung kecambah kedelai memiliki warna yang sedikit kecoklatan yang terjadi karena adanya reaksi maillard. Reaksi maillard ini terbentuk karena adanya penambahan tepung kecambah kedelai yang pada dasarnya mengandung asam amino lisin. Asam amino lisin terbentuk dari dua gugus amin yang bersifat reaktif terhadap gula pereduksi sehingga menimbulkan warna coklat pada cookies.

\section{Aroma}

Berdasarkan hasil analisis ragam diketahui bahwa perlakuan penambahan tepung labu kuning dan tepung kecambah kedelai menunjukkan berpengaruh nyata terhadap penilaian organoleptik deskriptif aroma. Hasil uji lanjut Duncan's Multipe Range Test (DMRTo,05) dapat dilihat pada Tabel 8.

Tabel 8. Analisis organoleptik deskriptif penilaian organoleptik aroma biskuit tepung labu kuning dan tepung kecambah kedelai

\begin{tabular}{ccc}
\hline Perlakuan (TT : TKK : TLK) & $\begin{array}{c}\text { Rerata } \\
\text { Organoleptik } \\
\text { Aroma }\end{array}$ & Kategori \\
\hline T0 $(100 \%: 0 \%: 0 \%)$ & $2.16^{\mathrm{d}} \pm 0.56$ & tidak berbau khas labu kuning dan kecambah kedelai \\
T1 $(50 \%: 45 \%: 5 \%)$ & $3.42^{\mathrm{b}} \pm 0.94$ & Agak berbau khas labu kuning dan kecambah kedelai \\
T2 $(50 \%: 40 \%: 10 \%)$ & $2.91^{\mathrm{c}} \pm 0.97$ & Agak berbau khas labu kuning dan kecambah kedelai \\
T3 $(50 \%: 35 \%: 15 \%)$ & $2.88^{\mathrm{c}} \pm 0.94$ & Agak berbau khas labu kuning dan kecambah kedelai \\
T4 $(50 \%: 30 \%: 20 \%)$ & $2.78^{\mathrm{c}} \pm 0.97$ & Agak berbau khas labu kuning dan kecambah kedelai \\
T5 $(50 \%: 25 \%: 25 \%)$ & $3.92^{\mathrm{a}} \pm 0.77$ & berbau khas labu kuning dan kecambah kedelai \\
\hline
\end{tabular}

Keterangan: Angka-angka yang diikuti oleh huruf yang berbeda menunjukan beda nyata berdasarkan uji DMRT 0,05 taraf kepercayaan 95\%. TT (tepung terigu), TLK (tepung labu kuning), TKK (tepung kecambah kedelai) 
Penilaian panelis pada parameter aroma yang tertinggi di poroleh pada T5 (50\% tepung terigu : $25 \%$ tepung labu kuning : 25\% tepung kecambah kedelai). Adanya perbedaan aroma khas tepung labu kuning pada produk biskuit dipengaruhi oleh bahan substituen yang digunakan sebagai penambahan dalam pembuatan biskuit yaitu tepung labu kuning dan tepung kecambah kedelai. Proses pembentukan aroma terjadi pada saat pencampuran bahan (mixing), sampai menjadi adonan dan akan berlangsung sampai proses pengukusan sehingga terbentuklah aroma yang khas (Krissetiana, 2003).

Labu kuning mempunyai aroma yang khas sehingga semakin banyak substitusi labu kuning yang digunakan maka aroma khas labu kuning dan tepung kecambah kedelai dari biskuit akan semakin nyata. Sebaliknya semakin sedikit labu kuning yang digunakan maka aroma yang dihasilkan semakin tidaknyata. Winarno (2004) menyatakan bahwa komponen yang memberikan aroma adalah asam-asam organik berupa ester dan volatil. Secara kimia sulit dijelaskan mengapa senyawa-senyawa menyebabkan aroma yang berbeda. Karena senyawa - senyawa mempunyai struktur kimia dan gugus fungsional yang hampir sama (stereoisomer) kadang-kadang mempunyai aroma yang sangat berbeda, misalnya metanol, isometanol dan neometanol. Aroma tidak hanya ditentukan oleh satu komponen tetapi juga oleh beberapa komponen tertentu yang menimbulkan bau yang khas serta perbandingan berbagi komponen bahan (seperti tepung labu kuning dan tepung kecambah kedelai).

\section{Tekstur}

Berdasarkan hasil analisis ragam diketahui bahwa perlakuan penambahan tepung labu kuning dan tepung kecambah kedelai menunjukkan berpengaruh sangat nyata terhadap penilaian organoleptik tekstur dapat dilihat pada Tabel 9.

Tabel 9. Analisis organoleptik deskriptif penilaian organoleptik tekstur biskuit tepung labu kuning dan tepung kecambah kedelai

\begin{tabular}{ccc}
\hline Perlakuan (TT : TKK : TLK) & Rerata Organoleptik Tekstur & Kategori \\
\hline T0 $(100 \%: 0 \%: 0 \%)$ & $2.67^{\mathrm{b}} \pm 1.01$ & Agak keras \\
T1 $(50 \%: 45 \%: 5 \%)$ & $3.40^{\mathrm{a}} \pm 1.10$ & Agak keras \\
T2 $(50 \%: 40 \%: 10 \%)$ & $3.58^{\mathrm{a}} \pm 1.04$ & Keras \\
T3 $(50 \%: 35 \%: 15 \%)$ & $2.66^{\mathrm{b}} \pm 1.10$ & Agak keras \\
T4 $(50 \%: 30 \%: 20 \%)$ & $2.73^{\mathrm{b}} \pm 1.15$ & Agak keras \\
T5 $(50 \%: 25 \%: 25 \%)$ & $2.63^{\circ} \pm 1.10$ & Agak keras \\
\hline
\end{tabular}

Keterangan: Angka-angka yang diikuti oleh huruf yang berbeda menunjukan beda nyata berdasarkan uji DMRT 0,05 taraf kepercayaan 95\%. TT (tepung terigu), TLK (tepung labu kuning), TKK (tepung kecambah kedelai) 
Penilaian panelis pada parameter tekstur yang tertinggi di peroleh pada T2 (50\% tepung terigu : 40\% tepung labu kuning : 10\% tepung kecambah kedelai). Hal ini disebabkan karena tingkat kekerasan dan kereyahan berkaitan erat dengan perbedaan komposisi bahan dasarnya, terutama pada komposisi amilosa dan amilopektin. Kadar amilosa yang tinggi pada bahan akan mampu meningkatkan kerenyahan dari biskuit yang dihasilkan karena amilosa dalam bahan akan membentuk ikatan hidrogen dengan air dalam jumlah yang lebih banyak. Dengan demikian, saat proses pengovenan, air akan menguap dan meninggalkan ruang kosong dalam bahan dan membuat biskuit akan menjadi lebih renyah (Rahmanto,1994). Dengan demikian, semakin tinggi substitusi tepung labu kuning akan meningkatkan kekerasan biskuit karena terjadi penurunan volume biskuit karena tingkat pengembangan yang menurun dan disebabkan oleh kadar gluten yang berkurang sehingga gas yang didapatkan menurun (Dian, 2014).

Menurut Rudianto (2014), pada penelitian cookies substitusi tepung daun kelor dan tepung kembah kedelai yaitu, semakin banyak penambahan tepung daun kelor dan tepung kecambah menjadikan cookies semakin keras, hal ini terjadi karena kedua tepung tersebut mengandung protein yang cukup tinggi, sedangkan untuk membuat cookies yang digunakan adalah tepung rendah protein agar tekstur yang dihasilkan lebih renyah.

\section{Analisis Proksimat Biskuit}

Berdasarkan hasil uji organoleptik biskuit, maka dapat ditentukan biskuit terpilih terdapat pada perlakuan $\mathrm{T}_{1}$ dengan komposisi perlakuan (tepung terigu 50\%: 45\% Tepung labu kuning : 5\% tepung kecambah kedelai). Dari perlakuan uji oraganoleptik biskuit terpilih maka dapat dilakukan analisis proksimat meliputi kadar air, kadar abu, kadar lemak, kadar protein dan kadar karbohidrat. Adapun nilai gizi yang didapatkan dapat dilihat pada Tabel 10.

Tabel 10. Nilai Gizi Biskuit $\left(\mathrm{T}_{0}\right)$ dan Terpilih $\left(\mathrm{T}_{1}\right)$

\begin{tabular}{|c|c|c|c|c|}
\hline \multirow{2}{*}{ No } & \multirow{2}{*}{ Komponen (\%) } & \multicolumn{2}{|c|}{ Kode sampel } & \multirow{2}{*}{ SNI } \\
\hline & & Kontrol $\left(\mathrm{T}_{0}\right)$ & Perlakuan $\left(\mathrm{T}_{1}\right)$ & \\
\hline 1 & Kadar air & $9.36 \% \pm 0,06$ & $9.00 \% \pm 0,07$ & Maks $5 \%$ \\
\hline 2 & Kadar abu & $2.28 \% \pm 0,03$ & $3.62 \% \pm 0,02$ & Maks $1.6 \%$ \\
\hline 3 & Kadar protein & $7.90 \% \pm 0,20$ & $11.91 \% \pm 0,15$ & $\operatorname{Min} 9 \%$ \\
\hline 4 & Kadar lemak & $15.74 \% \pm 0,37$ & $17.98 \% \pm 0,15$ & Min $9.5 \%$ \\
\hline 5 & Kadar karbohidrat & $64.70 \% \pm 0,53$ & $57.46 \% \pm 0,08$ & $\operatorname{Min} 70 \%$ \\
\hline
\end{tabular}


Kadar Air

Berdasarkan hasil analisis pada Tabel 10 menunjukkan bahwa kadar air biskuit yang ditambahkan tepung labu kuning yang tertinggi terdapat pada perlakuan T0 (100\% Tepung terigu) dengan nilai rata-rata kadar air 9,363 $\%$, sedangkan biskuit pada perlakuan T1 (45\% Tepung labu kuning : 5\% Tepung kecambah kedelai : 50\% Tepung terigu) memiliki kadar air terendah 9,008. Syarat mutu kadar air biskuit berdasarkan SNI yaitu maksimal 5\% yang berarti biskuit tepung labu kuning tidak memenuhi standar SNI 01-2973-1992. Kadar air biskuit semakin tinggi seiring semakin banyak proporsi tepung labu kuning yang ditambahkan, sedangkan semakin banyak proporsi penambahan kecambah kedelai yang ditambahkan maka kadar air semakin menurun. Penurunan kadar air terjadi akibat adanya mekanisme pati dan protein, menyebabkan air tidak lagi dapat diikat dengan maksimum. Ikatan hidrogen yang terbentuk antara molekul pati dengan air akan berkurang dengan adanya interaksi antara pati dan protein. Hal ini disebabkan karena tepung labu kuning memiliki kadar air yang lebih tinggi dibandingkan tepung kecambah kedelai. Tepung labu kuning memiliki kandungan karbohidrat yang tinggi yaitu sebesar $68.72 \%$, terdiri dari pati yang jumlahnya sebesar $14.23 \%$. Sejalan dengan penelitian yang dilaporkan Tresnani et al. (2015) pada pembuatan snack bar substitusi tepung komposit ubi jalar kuning (Ipomea batatas L.) dan kecambah kedelai (glycine max L. Merr) Kadar air snack bar berkisar antara 6,63 - 9,66 g/100 gram. Hasil penelitian menunjukkan bahwa semakin tinggi proporsi tepung komposit maka kadar air snack bar semakin menurun. Penurunan kadar air tiap taraf perlakuan snack bar forvita bergantung pada kadar air bahan penyusunnya. Kadar air tepung terigu yakni $12 \mathrm{~g} / 100 \mathrm{~g}$ lebih besar dibandingkan kadar air tepung ubi jalar kuning dan tepung kecambah kedelai yang masing-masing adalah 7,28 g/100 g dan 4,59 g/100 g, sehingga semakin banyak proporsi tepung komposit, kadar air snack bar semakin rendah.

\section{Kadar Abu}

Berdasarkan hasil analisis pada Tabel 10 menunjukkan bahwa kadar abu biskuit dengan penambahan tepung labu kuning dan tepung kecambah kedelai dengan nilai rata-rata sebesar (3.629\%). Sedangkan kadar abu biskuit terendah sebesar (2.289 \%) Syarat mutu kadar abu biskuit berdasarkan SNI 01-2973-1992 yaitu maksimal 1,6\% yang berarti biskuit tepung labu kuning tidak memenuhi standar SNI 01-2973-1992. Hal ini diduga disebabakan karena kandungan mineral dalam produk biskuit dengan penambahan tepung labu kuning dan tepung kecambah kedelai yang memiliki kandungan mineral yang tinggi sehingga meningkatkan kadar abu pada produk biskuit. Sejalan dengan yang dilaporkan Lestrio et al (2014) pada penelitian fortifkasi tepung labu kuning pada pembuatan mie basah dimana kadar abu mie dalam penelitian ini meningkat seirig dengan meningkatnya 
presentase tepung labu kuning (berkisar antara 0,66\% dan 1,31\%) kenaikan kadar abu mie tepung labu kuning disebabkan karena mineral pada tepung labu kuning lebih tinggi di bandingkan tepung terigu.

menurut Apriyanto et al. (2018) pada penelitian biskuit berbahan dasar labu kuning dan tepung beras. Tingginya kadar abu biskuit dapat disebabkan karena adanya penambahan labu kuning yang mengandung residu anorganik dalam jumlah besar seperti Fosfor (64 mg/100g), Kalsium (45 mg/100g), dan Besi (1,4 mg/100g). Selain adanya kandungan mineral pada labu kuning, kandungan protein yang tinggi menjadi faktor meningkatnya abu pada biskuit. Fatkurahman et al. (2012) yang menyatakan bahwa besarnya kadar abu pada suatu produk pangan bergantung pada besarnya kandungan mineral pada bahan yang digunakan.

\section{Kadar Protein}

Berdasarkan hasil analisis pada Tabel 10 menunjukkan bahwa kadar protein biskuit dengan penambahan tepung labu kuning dan tepung kecambah kedelai dengan nilai rata-rata sebesar $(11,911 \%)$. Sedangkan kadar protein biskuit terendah sebesar (7,905\%). Syarat mutu kadar protein biskuit berdasarkan SNI 01-2973-1992 yaitu minimal 9\% yang berarti biskuit tepung labu kuning memenuhi standar SNI 01-2973-1992. Meningkatnya kadar protein pada biskuit perlakuan T1 (50\% Tepung terigu : 45\% Tepung labu kuning : 5\% Tepung kecambah kedelai) diduga di sebabkan karena adanya kandungan protein yang terdapat didalam tepung labu kuning dan tepung kecambah kedelai sehingga meningkatkan kandungan protein pada biskut. Sejalan dengan yang dilaporkan Ardwifa et al. (2016) pada penelitian biskuit substitusi pisang awak masak dan tepung kecambah kedelai Kandungan protein yang terdapat pada biskuit masing-masing sebesar 7,69\%, 13,7\%, 10,3\% ini menunjukkan sudah memenuhi syarat mutu biskuit menurut SNI 01-29731992 dengan minimum kadar protein sebesar 6\%. Biskuit dengan penambahan tepung kecambah kedelai menyumbang protein paling banyak dari ketiga perlakuan pada biskuit.

Menurut Widowati et al. (2001) protein meningkat seiring meningkatnya persentase tepung labu kuning hal ini disebabkan kadar protein yang tinggi pula pada labu kuning yaitu 11,14\%. Semakin tinggi persentase tepung labu kuning maka kadar protein dari tepung komposit juga semakin meningkat. Sedangkan Kadar protein pada kecambah kedelai sekitar 9 gram/100 gram bahan, sedangkan saat ditepungkan, kadar proteinnya menjadi $37,5 \mathrm{gram} / 100$ gram bahan.

\section{Kadar Lemak}

Berdasarkan hasil analisis pada Tabel 10 menunjukkan bahwa kadar lemak biskuit tertinggi dengan penambahan tepung labu kuning dan tepung kecambah kedelai dengan nilai rata-rata sebesar $(17,987 \%)$. 
Sedangkan kadar lemak biskuit terendah sebesar (15,743\%). Syarat mutu kadar protein biskuit berdasarkan SNI 012973-1992 yaitu minimal 9,5 \% maka kadar lemak pada biskuit sesuai dengan SNI 01-2973-1992. Hal ini di sebabkan karena kandungan lemak yang terdapat dalam labu kuning dan kecambah kedelai serta kandungan lemak yang ada pada margarine sehingga meningkatkan kadar lemak pada biskuit. Hal ini sejalan dengan pernyataan Hartini et al. (2016) urata kadar lemak komposit terigu dan sukun dengan penambahan tepung labu kuning mengandung kadar lemak sebesar 1,52 $\pm 0,09$ sampai dengan 2,35 $\pm 0,29$. penambahan tepung labu kuning pada tepung komposit berpengaruh terhadap kadar lemak tepung Tersulaku, yaitu semakin meningkat kadar lemak.

Menurut Saroinsong et al. (2015). Semakin tinggi penambahan persentase bubur labu kuning dan bubur ketan maka kandungan kadar lemak akan semakin meningkat berkisar 7,56 - 7,72\%. Menurut Purnamasari et al. (2015), lemak flakes talas meningkat seiring meningkatnya konsentrasi penambahan tepung labu kuning dan diikuti dengan menurunya proporsi tepung talas. Oleh sebab itu kadar lemak yang terdapat pada tepung labu kuning adalah 3,60\% sedangkan lemak talas sebesar 0,91\%. menurut (Amina dan Santosa, 2014) kadar lemak kejale dengan variasi komposisi bahan tepung kecambah jagung dan tepung kecambah kedelai menunjukkan kecenderungan peningkatan. Semakin tinggi tepung kecambah kedelai menunjukkan kadar lemak yang semakin tinggi.

\section{Kadar Karbohidrat}

Berdasarkan hasil analisis pada Tabel 10 menunjukkan kadar karbohidrat biskuit dengan penambahan tepung labu kuning dan tepung kecambah kedelai dengan nilai rata-rata sebesar $(64,706 \%)$. Sedangkan kadar karbohidrat biskuit terendah sebesar (57,464\%). Syarat mutu kadar karbohidrat biskuit berdasarkan SNI 01-2973-1992 yaitu minimal $70 \%$. penurunan kadar karbohidrat di akibat beberapa kandungan gizinya mengalami peningkatan seperti protein dan lemak. Sejalan dengan yang dilaporkan Ardwifa et al. (2016) pada penelitian biskuit substitusi pisang awak masak dan tepung kecambah kedelai dimana biskuit dengan subtitusi tepung pisang awak masak memberi kontribusi karbohidrat sebesar $61,95 \%$, biskuit dengan penambahan tepung kecambah kedelai 55,47\% dan biskuit dengan campuran tepung pisang dan kecambah kedelai mengandung 55,46\% karbohidrat. Menurut syarat mutu biskuit SNI 01-2973-1992 kandungan karbohidrat mencapai 70\% sedangkan biskuit substitusi tepung pisang awak masak dengan kecambah kedelai dengan tiga perlakuan belum mencapai $70 \%$.

Menurut Hartoyo dan Sunandar (2006) pada penelitian pemanfaatan tepung komposit ubi jalar putih (Ipomoea batatas L) kecambah kedelai (Glycine max L Merr.) dan kecambah kacang hijau (Virginia Radiata L) sebagai substituen parsial terigu dalam produk biskuit Kandungan karbohidrat pada biskuit kaya energi protein 
mengalami penurunan dibandingkan dengan kedua biskuit kontrol yaitu $60.65 \%$ akibat beberapa terjadinya peningkatan kandungan gizi lainnya, seperti protein dan lemak. Namun demikian, nilai kandungan karbohidrat pada biskuit komposit kaya energi protein sebesar bukanlah merupakan nilai yang buruk karena tetap dapat mensuplai kebutuhan energi yang cukup.

\section{Takaran Saji dan \%AKG (Angka Kecukupan Gizi)}

Angka Kecukupan Gizi (AKG) digunakan sebagai standar untuk mencapai status gizi ideal. AKG yang digunakan adalah angka kecukupan gizi makanan selingan berdasarkan rekomendasi menurut standar BPOM RI NO 9 Tahun 2016 tentang acuan label gizi. Nilai AKG makanan selingan berdasarkan rekomendasi adalah 25\% dari AKG harian. Takaran saji yang dianjurkan dalam penyajian produk biskuit adalah sebesar 40 gram. Perhitungan kontribusi zat gizi produk biskuit dapat dilihat pada Tabel 11.

Tabel 11. Perhitungan kontribusi zat gizi produk biskuit terhadap AKG harian per $40 \mathrm{~g}$ takaran saji (8 keping biskuit)

\begin{tabular}{ccccc}
\hline Perlakuan & Zat Gizi & Per 40 g takaran saji & $\begin{array}{c}\text { AKG (Makanan } \\
\text { Selingan }\end{array}$ & $\begin{array}{c}\text { Kontribusi } \\
\text { zat gizi produk }\end{array}$ \\
\hline \multirow{3}{*}{ T0 } & Energi (kal) & 444,13 & 357,5 & 124,23 \\
& Protein & 3,16 & 15 & 18,87 \\
& Karbohidrat & 25,88 & 81,25 & 31,85 \\
& Lemak & 6,29 & 16,75 & 41,97 \\
T1 & Energi (kal) & 439.38 & 357.5 & 122,90 \\
& Protein & 4,76 & 15 & 28,44 \\
& Karbohidrat & 22,98 & 81.25 & 28,29 \\
& Lemak & 7,15 & 16.75 & 47,72 \\
\hline
\end{tabular}

Keterangan : *25\% nilai makanan selingan berdasarkan rekomendasi menurut standar BPOM RI No. 9 Tahun 2016. To (0\% Tepung labu kuning : $0 \%$ tepung kecambah kedelai : 100\% Tepung terigu) dan $\mathrm{T}_{1}(45 \%$ Tepung labu kuning : 5\% Tepung kecambah kedelai : $50 \%$ Tepung terigu)

Biskuit mengandung energi yang tinggi yaitu $124,23 \mathrm{kkal} / 40 \mathrm{~g}$. Tingginya energi pada T0 (100\% tepung terigu) disebabkan karena pada perlakuan ini memiliki kandungan karbohidrat yang tinggi dibandingkan perlakuan yang lain. Hal ini sesuai dengan IOM (2002) yang menyatakan energi merupakan salah satu hasil metabolisme karbohidrat, protein dan lemak. Maka semakin tinggi kandungan protein, karbohidrat dan lemak yang terkandung pada suatu produk maka semakin tinggi pula kalori yang diperoleh. 


\section{KESIMPULAN}

Perlakuan penambahan tepung labu kuning dan tepung kecambah kedelai berpengaruh sangat nyata terhadap penilaian organoleptik warna,aroma, rasa, dan tekstur. Perlakuan terbaik T1 (50\% tepung terigu : 45\% tepung labu kuning : 5\% tepung kecambah kedelai) warna memiliki nilai kesukaan sebesar 3.56 (suka), aroma memiliki nilai sebesar 3.40 (agak suka), rasa memiliki nilai sebesar 3.52 (suka) dan tekstur memiliki nilai sebesar 3.64 (suka). Kandungan gizi perlakuan terbaik T1 terdiri dari kadar air 9,00\%, kadar abu 3,62\%, kadar protein 11,91\%, kadar lemak 17,98\%, kadar karbohidrat 57,46\%. Berdasarkan standar SNI biskuit kadar air, kadar abu dan kadar karbohidrat tidak memenuhi standar SNI sedangkan untuk kadar protein dan kadar lemak telah memenuhi standar SNI. Takaran saji dalam penyajian produk biskuit sebesar $40 \mathrm{~g}$ dan \%AKG (Angka Kecukupan Gizi) pada biskuit terpilih yaitu perlakuan T1 (50\% tepung terigu : 45\% tepung labu kuning : 5\% tepung kecambah kedelai) menyumbang energi sebesar 122,90 kalori, protein 28,44 karbohidrat 28,29, lemak 47,72\% dari kebutuhan makanan selingan sebagai upaya kontribusi kecukupan gizi.

\section{DAFTAR PUSTAKA}

Astawan M. 2009. Sehat Dengan Hidangan Kacang dan Biji - bijian. Depok. Swadaya

Asmaraningtyas D. 2014. Kekerasan, Warna dan Daya Terima Biskuit Yang Disubstitusi Tepung Labu Kuning. Skripsi. Program Studi IImu Gizi Jenjang S1 Fakultas Ilmu Kesehatan Universitas Muhammadiyah Surakarta.

Avianty S dan Ayustaningwarno F. (2013). Kandungan Zat Gizi Dan Tingkat Kesukaan Snack Bar Ubi Jalar Dan Kedelai Hitam Sebagai Alternatif Makanan Selingan Penderita Diabetes Melitus Tipe 2. Journal of Nutrition College, 2(4) : 622-629.

Dhiman AK, Sharma KD, dan Attri S. 2009. Functional constituents and processing of pumpkin: a review. J Food Sci Technol-Mys 4(6) : 411- 417.

Hendrasty HK. 2003. Tepung Labu Kuning. Kanisius. Yogyakarta.

Kusnandar F. 2010. Komponen Makro Kimia Pangan, Dian Rakyat. Jakarta.

Khaidar H. 2016. Karakteristik Fisikokimia Tepung Kedelai dan Tepung Kecambah Kedelai. Laporan Skripsi. Fakultas Teknologi Pertanian. IPB. Bogor. 
Kurniasih D, Hilmansyah H, Astuti, MP, dan Imam S. 2010. Sehat dan Bugar Berkat Gizi Seimbang. Gramedia Jakarta.

Laura and Jenifer. 2006. Encouraging Preschoolers to Try New Foods. Beyond the journal. 4(2):92-97.

Muchtadi D. 2010. Teknik Evaluasi Nilai Gizi Protein. Alfabeta Bandung.

Murphy SP, Gew C, Grillenberger C, Bwibo M, dan Neumann NO. 2007. Designing Snacks to Address Micronutrient Deficiencies in Rural Kenyan School children. J. Nutr. 1(37) : 1093-1096.

Nurdjanah S, Astuti S, Musita N, dan Febriyaningsih T. 2014. Sifat Sensory Biskuit Berbahan Baku Tepung Jagung Ternikstamalsasi dan Terigu. Laporan Skripsi. Jurusan Teknologi Hasil Pertanian. Universitas Lampung. Lampung.

Nwamaka NO. 2008. Yogurt fortifi cation with predigested/germinated whole soybean powder for enhanced therapeutic benefi ts (Doctor's thesis, Michigan State University, USA).

Permatasari KBD, Putu TI, dan Ni MY. 2013. Pengaruh Penggunaan Tepung Labu Kuning (Cucurbita moschata Duch) Terhadap Karakteristik .Chiffon Cake Berbahan Dasar Modified Cassava Flour (Mocaf) Jurnal Itepa. 7(2) : 72-77.

Que F, Mao L, Fang X, dan Wu T. 2008 Comparison of hot air-drying and freeze drying on the physiochemical properties and antioxidant activities of pumpkin (Cucurbita moshata Duch) flours. Intj FoodSci Technol $4(3): 1195-1201$.

Rahmanto F. 1994. Tehnologi Pembuatan Keripik Simulasi dari Talas Bogor Colocasia esculenta (L) SHOTT). Skripsi. Fakultas Tehnologi Pertanian. IPB. Bogor.

Rudianto. 2014. Studi Pembuatan Dan Analisis Zat Gizi Pada Produk Biskuit Moringa Oleifera Dengan Substitusi Tepung Daun Kelor (Tesis). Skripsi. Universitas Hasanudin. Makassar.

Sari KY, dan Adi CA. 2012. Daya Terima, Kadar Protein dan Zat Besi Cookies Subtitusi Tepung Daun Kelor dan Tepung Kecambah Kedelai Media Gizi Indonesia. 12(1) : 27-33

See EF, Wan NWA, dan Noor AAA. 2007. Physico-chemical and sensory evaluation of breads supplemented with pumpkin flour. ASEAN Food Journal, 14(2):123-130.

Tresnani AR, Razak M, dan Suswati K I. 2015. Substitusi Tepung Komposit Ubi Jalar Kuning (Ipomea Batatas L.) dan Kecambah Kedelai (Glycine max L. Merr) Pada Pembuatan Snack Bar Forvita Bagi Balita Gizi Buruk Fase Rehabilitasi Terhadap Mutu Kimia, Nilai Energi, Mutu Protein, Mutu Fisik dan Mutu Organoleptik. Jurnal ilmiah - vidya . 25(1) : 144-158

Utami ER. 2012. Antibiotika, Resistensi, dan Rasionalitas Terapi. Sainstis. 1(1):158-164

Winarno FG. 2004. Kimia Pangan dan Gizi. Gramedia Pustaka Utama. Jakarta

Zulfa NI. 2013. Nilai Cerna Protein In Vitro dan Organoleptik MP-ASI Biskuit Bayi dengan Substitusi Tepung Kedelai, Tepung Ubi Jalar Kuning dan Pati Garut. Artikel Penelitian. Program Studi IImu Gizi Fakultas Kedokteran Universitas Diponegoro. Semarang 